\title{
PERAN GURU SERTA PROSES PERENCANAAN, PENGAWASAN, DAN EVALUASI DALAM ADMINISTRASI KURIKULUM DI SEKOLAH
}

\author{
Monalisa Rahman \\ Program Studi Pendidikan IPS Fakultas Keguruan dan Ilmu Pendidikan \\ Universitas Lambung Mangkurat \\ Banjarmasin \\ e-mail:2010128220010@mhs.ulm.ac.id
}

\begin{abstract}
Abstrak
Satu aspek yang memiliki pengaruh besar dalam pencapaian keberhasilan suatu pendidikan ialah kurikulum. Kurikulum ialah suatu elemen yang urgen dan menjadi penentu dalam pelaksanaan pendidikan. Kurikulum berfungsi sebagai alat guna mencapai tujuan pendidikan. Dalam dunia pendidikan, pentingnya peranan kurikulum pastinya juga harus mempunyai pengelolaan yang baik, maka diperlukannya proses adminisrasi yang disebut dengan administrasi kurikulum. Administrasi ini sangat diperlukan bagi keberlangsungan proses pembelajaran dalam dunia pendidikan. Administrasi kurikulum adalah keseluruhan proses aktivitas yang direncanakan dan diupayakan secara sengaja dan bersungguh-sungguh serta pembinaan secara kontinyu pada suasana proses pembelajaran serta efektif dan efisien guna membantu tercapainya tujuan pendidikan yang telah diputuskan. Adapun penulisan artikel ini yaitu menggunakan metode pendekatan kualitatif yaitu dengan menelaah dan memahami isi buku-buku, dokumen, skripsi atau jurnal-jurnal ilmiah lainnya yang relevan dan mendukung untuk menggambarkan atau mendeskripsikan peran guru serta proses perencanaan, pengawasan, dan evaluasi dalam administrasi kurikulum di sekolah.
\end{abstract}

Kata Kunci: Administrasi, Kurikulum, Pendidikan

\section{PENDAHULUAN}

Salah satu komponen yang mempunyai pengaruh besar dalam mencapai keberhasilan suatu pendidikan ialah kurikulum. Kurikulum dalam definisi sempit ialah satuan mata pelajaran yang diikuti oleh siswa guna menamatkan sekolahnya pada satuan lembaga pendidikan tertentu. Dan sedangkan dalam definisi luas kurikulum ialah suatu pengalaman belajar yang diberikan sekolah kepada siswa sewaktu mengikuti pembelajaran pada jenjang pendidikan tertentu. Adapun menurut Sanjaya, 2008 dan Prihantoro, 2015), kurikulum merupakan seperangkat perencanaan dan pengauran terkait tujuan isi dan bahan pelajaran dan strategi yang difungsikan sebagai dasar pelaksanaan aktivitas pembelajaran guna mencapai tujuan tertentu. Kurikulum disusun oleh satuan pendidikan guna penyesuaian program pendidikan dengan kebutuhan dan kemampuan yang ada di daerah.

Kurikulum ialah suatu elemen yang urgen dan menjadi penentu dalam pelaksanaan pendidikan. Kurikulum berfungsi sebagai alat guna mencapai tujuan pendidikan. Jika tujuan pendidikan berubah maka kurikulum juga ikut berubah dan harus diubah. Kurikulum berfungsi bagi siswa yaitu sebagai fasilitas guna mengembangkan seluruh potensi yang 
dipunyai untuk menuju ke arah yang lebih baik atas didikan dan bimbingan para guru di sekolah. Dan bagi guru, kurikulum berguna sebagai dasar atau pijakan dalam pelaksanaan pembelajaran di sekolah.

Dalam dunia pendidikan, pentingnya peranan kurikulum pastinya juga harus mempunyai pengelolaan dengan baik, maka diperlukannya proses adminisrasi yang disebut dengan administrasi kurikulum. Administrasi ini sangat diperlukan bagi keberlangsungan proses pembelajaran dalam dunia pendidikan. Semua itu tidak luput dari keaktifan orangorang yang ahli dalam penguasaan administrasi dalam sekolah. Perekrutan orang yang bekerja dibidang administrasi pun tidak sembarangan. Apabila pengadminisrasian dipegang atau dikelola oleh orang yang tidak terampil maka proses administrasi itu akan kacau atau tidak teratur dan tidak tersusun. Oleh karenanya orang yang menjabat adminisrasi ini harus orang yang sudah terlatih dalam bidangnya. Dan apabila administrasi sudah dipegang oleh orang yang ahli dibidangnya maka pengelolaan administrasi tersebut dapat terlaksana dengan baik dan hasil akhirnya dapat menunjang keberhasilan sebuah pendidikan.

Administrasi kurikulum adalah keseluruhan proses aktivitas yang direncanakan dan diupayakan secara sengaja dan bersungguh-sungguh serta pembinaan secara kontinyu pada suasana proses pembelajaran serta efektif dan efisien guna membantu tercapainya tujuan pendidikan yang telah diputuskan.

Jadi tujuan penulisan artikel ini ialah untuk mendeskripsikan peranan administrasi kurikulum, proses pelaksanaan atau tahap-tahap administrasi kurikulum dan peranan seorang guru dalam pelaksanaan administrasi kurikulum. Jika administrasi kurikulum telah berjalan sebagaimana seharusnya maka tujuan dari pendidikan itu kan terlihat keberhasilannya.

\section{METODE}

Metode atau teknik yang dipergunakan pada penyusunan jurnal atau artikel ini ialah teknik atau metode pendekatan kualitatif yaitu studi kepustakaan atau studi literatur yaitu dengan mencari, menelaah dan memahami isi buku-buku, dokumen, skripsi atau jurnal-jurnal ilmiah lainnya yang relevan dan mendukung untuk menggambarkan atau mendeskripsikan mengenai peranan administrasi kurikulum, proses pelaksanaan atau tahap-tahap administrasi kurikulum dan peranan seorang guru dalam pelaksanaan administrasi kurikulum. Situs yang digunakan dalam penulisan artikel ini ialah seperti Google Scholar, dan data yang diperoleh ada 12 jurnal yang menggunakan kata kunci: (i) administrasi (ii) kurikulum dan (iii) peranan. Masing-masing dari 12 jurnal tersebut dibaca dengan cermat dari abstrak hingga kesimpulan, untuk memperoleh informasi berkaitan dengan peranan administrasi kurikulum, proses 
pelaksanaan atau tahap-tahap administrasi kurikulum dan peranan seorang guru dalam pelaksanaan administrasi kurikulum.

\section{PEMBAHASAN}

Seiring perkembangan pendidikan maka konsepsi kurikulum juga ikut berkembang. Ada beberapa variasi aliran pemikiran dan teori-teori yang dijunjungnya. Nilai kurikulum tidak hanya bisa dilihat dari dokumen tertulis. Demikian harus dinilai dari penerapan, pelaksanaan dan pengamalannya di kelas. Kurikulum tidak hanya rencana proses pengajaran tertulis. Tapi juga merupakan fungsi yang beroperasi di kelas, dasar, acuan dan peraturan untuk lingkungan dan kegiatan di kelas ini. Demikian kurikulum bisa dipahami sebagai seperangkat aturan yang harus dilakukan, dijalani dan dipraktikkan kepada siswa untuk mencapai suatu gelar atau sertifikat tertentu (Ahid, 2015).

Pendidikan formal telah mempunyai rencana atau rancangan pendidikan berupa kurikulum tertulis yang tersusun secara sistematis, rinci dan jelas. Dalam peyelenggaraannya, dilakukan pengawasan (controlling) dan evaluasi atau penilaian guna mengetahui tingkatan pencapaian kurikulum. Dalam pendidikan formal di sekolah, peran kurikulum sangat penting dan strategis dalam penentuan tercapainya tujuan pendidikan. Selain itu kurikulum juga mempunyai kedudukan yang terpusat dalam keseluruhan berjalannya proses pendidikan, bahkan kurikulum itu merupakan suatu keharusan dan bagian yang tidak dapat dipisahkan dari pendidikan. Sulit dibayangkan jika pelaksanaan proses pendidikan di suatu lembaga pendidikan yang tidak menggunakan kurikulum (Asep Hernawan Herry \& Andriyani, 2014).

\section{PROSES ADMINISRASI KURIKULUM}

Dalam administrasi kurikulum terdapat beberapa tahapan yaitu: perencanaan, pelaksanaan, pengawasan dan evaluasi. Berikut penjelasannya:

\section{a. Perencanaan}

Pada proses perencanaan terdapat beberapa tahapan yaitu:

1. Identifikasi masalah

Pada tahap identifikasi masalah, ada beberapa prinsip yang harus menjadi pertimbangan dan perlu diperhatikan dalam perancangan dan pelaksanaan kurikulum yaitu diantaranya:

- Prinsip relevansi

Tujuan, isi, dan proses pembelajaran harus relevan dengan tuntutan, kebutuhan dan perkembangan masyarakat dan harus sesuai dan konsisten antara aspek- 
aspek kurikulum, yakni antara tujuan, isi, proses penyampaian dan evaluasi yang menunjukkan keserasian kurikulum.

- Prinsip efektivitas

Efektifitas berkaitan dengan berhasilnya penyelenggaraan kurikulum baik itu kuantitas ataupun kualitasnya. Dalam pengembangannya, harus diperhatikan hubungan antara komponen utama kurikulum yakni isi, tujuan, pengalaman belajar, serta evaluasi dengan kebijakan pemerintah dalam bidang pendidikan.

- Prinsip efisiensi

Kurikulum dalam pendidikan selalu diselenggarakan dalam keterbatasan, keterbatsan ini maksudnya ialah keterbatasan waktu, biaya, fasilitas, ataupun personalia. Kurikulum harus mudah dijalankan, praktis dan menggunakan alatalat sederhana dan memerlukan biaya yang murah.

- Prinsip kontinuitas

Kurikulum hendaknya berkelanjutan antara tingkatan kelas dan antara per jenjang pendidikan, serta antara jenjang pendidikan dengan pekerjaan. Karena proses belajar dan pengalaman belajar anak yang berlangsung secara berkesinambungan.

- Prinsip fleksibilitas

kurikulum harus memuat suatu hal yang solid, tapi dalam pelaksanaannya mungkin akan terjadinya pengadaptasian yang didasarkan pada keadaan daerah, waktu ataupun kemampuan, dan latar belakang anak.

2. Menentukan tujuan

Kurikulum tidak bisa dibuat secara sembarangan. Perumusan dan penyusunan kurikulum memerlukan asas landasan yang kuat, yang didasarkan pada buah pemikiran dan melalui riset yang mendalam. Kurikulum disusun guna membentuk tujuan pendidikan nasional dengan memperhatikan tahapan perkembangan peserta didik dan sesuai dengan lingkungan. Perkembangan IPTEK dan kesenian, sesuai dengan jenis dan jenjang satuan pendidikan merupakan kebutuhan pembangunan nasional (Sufairoh, 2010).

Aktivitas utama dalam mengelola kurikulum ialah mencakup perencanaan dan pengembangan, pelaksanaan, evaluasi dan perbaikan kurikulum. Perencanaan dan pengembangan kurikulum berdasarkan pada pendapat bahwa sudah tersedia data dan informasi tentang permasalahan dan keperluan yang mendasari disusunnya 
perencanaan. Lalu pelaksanaan kurikulum berdasarkan pada pendapat bahwa kurikulum sudah direncanakan dengan baik dan sudah siap dipraktekkan. Dengan begitu, perencanaan dan pengembangan kurikulum, pelaksanaan, penilaian dan perbaikan kurikulum dalam satu sistem atau siklus yang berkelanjutan, bertahap, bergilir, dan berkesinambungan dalam lingkaran proses sistem pendidikan yang menyeluruh (Nasir \& Samarinda, 2016).

\section{PENGAWASAN KURIKILUM}

Pengawasan ialah semua kegiatan yang dijalnkan oleh pihak manajemen dalam usaha memastikan bahwa hasil terbaru sesuai dengan hasil yang direncanakan. Pengawasan ialah fungsi administratif bagi tiap administrator guna memastikan bahwa apa yang ia dikerjakan dan lakukan sesuai dengan yang diinginkan. Pengawasan itu meliputi pemeriksaan apakah semua berjalan sesuai dengan rencana yang dibuat, instruksi-instruksi yang dikeluarkan dan prinsipprinsip yang ditetapkan. (Afriansyah, 2019).

\section{EVALUASI KURIKULUM}

Evaluasi hasil belajar terbagi menjadi dua, yaitu: evaluasi hasil belajar dan evaluasi program pengajaran. Berikut penjelasannya:

a. Evaluasi Hasil Belajar

Evaluasi hasil belajar adalah suatu aktivitas yang dilakukan untuk memberikan informasi secara menyeluruh terkait proses dan hasil belajar yang telah dicapai siswa. Tujuan dan fungsi evaluasi hasil belajar adalah:

1. memberikan proses umpan balik antara guru dan siswa bertujuan untuk memperbaiki cara proses belajar mengajar, mengadakan pengayaan dan perbaikan bagi siswa, dan menempatkan siswa pada keadaan belajar mengajar yang sesuai dengan kemampuan yang dimilikinya.

2. memberikan informasi terhadap siswa terkait tingkat keberhasilannya dalam belajar yang bertujuan guna memperluas atau mendalami pelajaran.

3. menentukan nilai hasil belajar siswa yang diperlukan guna pemberian laporan hasil belajar kepada orang tua, penentuan kenaikan kelas, dan kelulusan siswa.

b. Evaluasi Program Pengajaran

Evaluasi program pengajaran adalah suatu serangkaian aktivitas yang dilaksanakan untuk melihat tingkat keberhasilan program, serta faktor pemicu yang mendukung atau menghambat keberhasilan program tersebut (Afriansyah, 2019). 


\section{PERAN GURU DALAM ADMINISTRASI KURIKULUM}

Dalam adminintrasi kurikulum, terdapat peranan seorang guru yaitu sebagai implementers, adapters, researchers dan researchers. Berikut penjelasannya:

\section{a. Implementers}

Guru menerima suatu kebijakan dari perumus kurikulum, dalam mengoperasikan kurikulum dan dalam menjalankan perannya. Dalam pengembangan kurikulum guru ditugasi untuk bisa bertanggung jawab dalam mengaplikasikan berbagai ketentuan yang ada. Maka diharapkan tingkat inovasi dan kreativitas guru dalam merngaplikasikan pembelajaran sangat diperlukan.

b. Adapters

Guru berperan sebagai penyesuaian dan penyelaras kurikulum dengan ciri-ciri dan kebutuhan siswa. Guru diberi tugas untuk menyesuaikan kurikulum yang sudah ada dengan karakter sekolah dan kebutuhan lokal. Hal ini, tepat dengan kebijakan KTSP dimana para perumus kurikulum hanya menetapkan standar isi sebagai standar minimal yang harus dicapai.

c. Developers

Guru berperan sebagai pengembang kurikulum dan mempunyai tugas dalam menyusun dan mendesain kurikulum. Guru tidak hanya menetapkankan tujuan dan materi pembelajaran yang disampaikan, tapi guru juga dapat menetapkan stategi apa yang cocok dan sesuai dalam proses pembelajaran.

\section{d. Researchers}

Guru berperan sebagai peneliti atau pencari, yang dilakukan sebagai tugas profesional guru yang mempunyai tanggung jawab dalam mengembangkan kinerjanya. Dalam menjalankan perannya sebagai peneliti, guru mempunyai tanggung jawab untuk menguji berbagai aspek kurikulum, seperti menguji bahan-bahan kurikulum, menguji keefektifitasan program, menguji strategi dan model pembelajaran dan lain sebagainya termasuk mngumpulkan data tentang hasil evaluasi siswa dalam capaian target kurikulum. Metode yang digunakan oleh guru dalam meneliti kurikulum ialah Lesson study dan PTK (Penelitian Tindakan Kelas) (Afriansyah, 2019).

\section{SIMPULAN}

Salah satu komponen yang mempunyai pengaruh besar dalam mencapai keberhasilan suatu pendidikan ialah kurikulum. Kurikulum ialah suatu elemen yang urgen dan menjadi penentu dalam pelaksanaan pendidikan. Kurikulum berfungsi sebagai alat guna mencapai 
tujuan pendidikan. Jika tujuan pendidikan berubah maka kurikulum juga ikut berubah dan harus diubah. Bagi siswa, kurikulum berfungsi sebagai alat untuk mengembangkan segenap potensi yang dipunyai menuju ke arah yang lebih baik di bawah didikan dan bimbingan para guru di sekolah. Dan bagi guru, kurikulum berguna sebagai dasar atau pijakan dalam pelaksanaan pembelajaran di sekolah.

Administrasi kurikulum adalah keseluruhan proses aktivitas yang direncanakan dan diupayakan secara sengaja dan bersungguh-sungguh serta pembinaan secara kontinyu pada suasana proses pembelajaran serta efektif dan efisien guna membantu tercapainya tujuan pendidikan yang telah diputuskan. Adapun dalam proses administrasi kurikulum yaitu ada perencanaan, menentukan tujuan, pelaksanaan kurikulum, pengawasan kurikulum dan evaluasi kurikulum. Kemudian peranan guru dalam pengadministrasian kurikulum ialah guru sebagai implementers, adapters, developers, dan Researcher.

\section{DAFTAR PUSTAKA}

Efendi, A., \& Afriansyah, H. (2019). Administrasi Kurikulum.

Kurikulum, A. P. Pengertian dan proses administrasi kurikulum.

Kartiwi, A. P. (2018). Analisis Administrasi Kurikulum Pada Sekolah Menengah Atas Swasta Tunas Baru Ciparay. Edum Journal, 1(1), 50-61.

Hidayah, L. (2020). Pelaksanaan Administrasi Kurikulum Dalam Proses Pembelajaran Di Madrasah Tsanawiyah Al-Kautsar Sumbersari Srono Banyuwangi Tahun Pelajaran 2019/2020 (Doctoral Dissertation, Institut Agama Islam Negeri (Iain) Jember).

Luthfiah, L., \& Afriansyah, H. (2019). Administrasi kurikulum.

Afriansyah, H. (2019). 2. ADMINISTRASI KURIKULUM.

Ningrum, E. S., \& Sobri, A. Y. (2015). Implementasi kurikulum 2013 di sekolah dasar. Jurnal Manajemen Pendidikan, 24(5), 416-423.

Masluroh, H. (2017). Sistem Online Administrasi Kurikulum Sebagai Solusi Perbaikan Layanan Administrasi Di Sma Nahdlatul Ulama 1 Gresik. DIDAKTIKA: Jurnal Pemikiran Pendidikan, 19(2), 1-10.

Tjeriawan, C. A., \& Afriansyah, H. (2019). Administrasi Kurikulum.

Nirmala, R., \& Afriansyah, H. (2020). Administrasi Kurikulum.

Iswayuni, D., Adyatma, S., \& Rahman, A. M. (2020). Hubungan Motivasi Belajar dengan Hasil Belajar Geografi Siswa SMA Negeri 1 Kurau dan SMA Negeri 1 Bumi Makmur. JPG (Jurnal Pendidikan Geografi), 6(2). 
Mutiani, M., Abbas, E. W., Syaharuddin, S., \& Susanto, H. (2020). Membangun Komunitas Belajar Melalui Lesson Study Model Transcript Based Learning Analysis (TBLA) dalam Pembelajaran Sejarah. Historia: Jurnal Pendidik dan Peneliti Sejarah, 3(2), 113-122. 